\title{
Microstructural and Electrochemical behaviour of Aluminium Alloy Composites Produced Using Different Sintering Techniques
}

\author{
Muthuchamy A. ${ }^{a}$, A. Raja Annamalai ${ }^{*}{ }^{\circledR}$, Swati Ghosh Acharyyac ${ }^{c}$, Nidhi Nagaraju ${ }^{a}$, Dinesh K Agrawal ${ }^{d}$ \\ ${ }^{a}$ School of Mechanical Engineering, VIT University, Vellore - 632014, Tamil Nadu, India \\ ${ }^{b}$ Centre for Innovative Manufacturing and Research (CIMR), VIT University, Vellore - 632014, Tamil \\ $\mathrm{Nadu}$, India \\ ${ }^{c}$ School of Engineering Sciences and Technology University of Hyderabad, Gachibowli, Hyderabad, India \\ ${ }^{d}$ Materials Research Institute, The Pennsylvania State University, University Park, PA 16802, USA
}

Received: March 27, 2017; Revised: January 18, 2018; Accepted: February 09, 2018

\begin{abstract}
Present research work analyses the effect of heating modes on the densification, microstructure and mechanical properties of aluminum alloys [ $65 \mathrm{Al}-20 \mathrm{Cu}-15 \mathrm{Mn}$ ] fabricated through powder metallurgy route. Sintering of compacts using conventional, microwave and spark plasma sintering methods has been carried out at $525^{\circ} \mathrm{C}$. From the results, it has been observed that the spark plasma sintering method produced the samples with better mechanical properties than the other two methods, followed by microwave and conventionally sintered counterparts. Microstructural analysis using optical microscopy revealed that spark plasma sintered sample has finest microstructure due to faster rate of heating than microwave and conventional methods.
\end{abstract}

Keywords: Conventional, microwave, spark plasma, sintering, mechanical properties.

\section{Introduction}

Aluminum (Al) was selected in this study due to its distinctive characteristics, such as low density $\left(2.7 \mathrm{~g} / \mathrm{cm}^{3}\right)$ and combination of moderate strength, and high ductility, thermal conductivity, electric conductivity, corrosion-resistance ${ }^{1}$. In common practice, casting techniques are used to manufacture Al based products. Unfortunately, casting techniques give rise to microcracks. Hence, powder metallurgy $(\mathrm{P} / \mathrm{M})$ routes are used to avoid segregations in bulk production of alloys and to obtain uniform microstructures in complex components ${ }^{2,3}$. The application of $\mathrm{P} / \mathrm{M}$ aluminum alloys has been increasing in locomotive industry where low cost lightweight materials are the essential design parameters. The $\mathrm{P} / \mathrm{M}$ aluminum alloys are gradually replacing Aluminium die casting that entail accurate net shaping and improved material utilization ${ }^{4}$. It is a well-known fact that pure aluminium is highly ductile and addition of copper reduces the excess ductile that helps in precipitation hardening. As copper content increases hardness increases and so the tensile strength ${ }^{5}$. Increasing content of copper have noimpact on the corrosive properties of the alloy. Aluminium-copper alloys are heat-treatable and possess high strength (especially at high homologous temperature) and high toughness to make them for a wide range of applications in aircraft and transportation industry ${ }^{6}$. Aluminium-manganese alloys have high formability, corrosion resistance with high heat transfer coefficient and hence are good for radiators, packaging and roofing applications ${ }^{7}$.
Manganese quantity exceeding 0.5 weight percent in $\mathrm{Al}$ alloys increases yield and tensile strengths without compromising the ductility. Accruement of Mn leads to the development of $\mathrm{Mn}$ dispersoid of $\mathrm{Al}_{6} \mathrm{Mn}$. Consequently, the motion of dislocation is hindered which increases strength. After blockage, slip system is modified through cross-slip. The presence of cross-slip helps in maintaining uniform ductility and considerably provides better fatigue resistance ${ }^{7}$. Mn addition also gives good corrosion resistance. Thus our goal of this work has been to make an alloy with increasing strength, lowering ductility and improvement in the low cycle fatigue resistance, This can be achieved by $\mathrm{Al}-\mathrm{Cu}-\mathrm{Mn}$ alloys ${ }^{6-7}$. Microwave sintering has been used widely for sintering of ceramics and hard metals, until Roy et.al ${ }^{8}$ showed effective coupling of microwaves and metals in powder form. Later on many researchers have reported microwave sintering of many compacts fabricated through powder metallurgy and alloyed compositions (steel, stainless steel, copper, Al, Ni, Mo Co, Ti, Sn, etc) to nearly full density with improved mechanical properties ${ }^{9-21}$. Spark plasma sintering (SPS) incorporates pressure to form solid powder in the presence of a pulsed direct current during the consolidation of powder in a graphite die. Remarkable advantages associated with this technique are short sintering cycle, high densification rates and fine microstructures. Xie et $\mathrm{al}^{22-23}$ have extensively studied the impact of SPS on air atomized pristine Al and $\mathrm{Mg}$-doped aluminium powders ${ }^{24-31}$. In the current work, a 
comparison of conventional, microwave and spark plasma sintering techniques has been done in order to improve densification and mechanical properties of the alloy chosen. There has been reported very little on the Microwave and spark plasma sintering of Al-Cu-Mn composites. In our study we compare the mechanical properties of the sintered samples of Al-Cu-Mn alloys by three sintering methods. A comparative analysis and explanation have been presented.

\section{Experimental Procedure}

The powders of $\mathrm{Al}, \mathrm{Mn}$ and $\mathrm{Cu}$ (purity $>96 \%$ and average particle size $<40 \mu \mathrm{m}$ ) in elemental form were blended to obtain nominal compositions of $\mathrm{Al}_{65} \mathrm{Cu}_{20} \mathrm{Mn}_{15}$. Commensurate blending of powders was carried out in a Turbula mixer for an hour. Compaction of cylindrical pellets using the mixed compositions was done at $400 \mathrm{MPa}$ by employing a $50 \mathrm{~T}$ hydraulic press with floating die. Green density of compacts was $\sim 72 \%$ of theoretical. Conventional sintering of green compacts was carried in a $\mathrm{MoSi}_{2}$ tubular furnace (Supplier: VB ceramics consultants, Chennai, India) with a heating rate of $5^{\circ} \mathrm{C} / \mathrm{min}$. in $\mathrm{H}_{2}$ with a dew point of (dew point: $-35^{\circ} \mathrm{C}$ ). The sintering temperature was set at $525^{\circ} \mathrm{C}$ for one hour. The sintered density was obtained through Archimedes principle. For microwave sintering $6 \mathrm{~kW}, 2.45$ $\mathrm{GHz}$, multimode microwave furnace microwave furnace (supplier: VB ceramics consultants, Chennai, India) was used in this study. The green compacts were placed in a multilayered insulation package was used to provide sufficient insulation to obtain high and uniform temperatures throughout the sample. A mullite tube was placed at the Centre of the package, and samples were placed in this mullite tube on a $1 \mathrm{~cm}$ thick layer of fused alumina powder for additional insulation. The samples were sintered using Microwave sintering machine at a heating rate of $40^{\circ} / \mathrm{min}$ and the holding time at sintering temperature 10 minutes, Temperature was monitored by IR pyrometer (Raytek, Marathon Series). The pyrometer being based on emissivity readings of temperature above $700^{\circ} \mathrm{C}^{32-34}$ were observed taking emissivity of $\mathrm{Al}$ as 0.04 . Generally, variation of emissivity with temperature is observed. But very low variation in the emissivity was noted in the temperature range under the present study. For SPS experiments a DR. Sinter 21050 spark plasma sintering furnace was used. Prior to sintering, flushing and back-filling of spark plasma sintering furnace with argon was conducted thrice, with final evacuation to a vacuum of 2 Pascal. The samples were sintered using spark plasma sintering machine at a heating rate of $100 \% \mathrm{~min}$ and the holding time at sintering temperature is 5 mins, following which the samples were allowed to furnace cool. There was constant application of uniaxial pressure of $50 \mathrm{MPa}$ throughout the process. AK-type thermocouple was employed for measuring the temperature. EDM was employed to cut sintered discs in order to provide metallography samples as well as samples for tensile and hardness tests. The polished sintered samples were prepared using emery sand paper and diamond paste followed by etching with Keller's reagent. These samples were examined for their microstructures under the Leica optical microscope at 200X magnification. Vickers micro hardness tester was used to determine Micro-hardness at an indentation load of $20 \mathrm{~g}$ with a dwell time of ten seconds. The micro hardness value was calculated using the following formula.

Vickers micro hardness value $=\frac{1.854 \mathrm{P}}{l^{2}}$

Where,

$\mathrm{P}=$ Applied load (gm)

$1=$ Average length of the diagonals $d_{1}$ and $d_{2}$

The mechanical properties were measured using tensile bars following MPIF standard procedure with gauge length 26 $\mathrm{mm}$ and full-load $20 \mathrm{kN}$ with an initial strain rate of $3.3 \times 10^{-4}$ $\mathrm{s}^{-1}$. For determining electrochemical behaviour of Al-Cu-Mn alloys, all samples were polished and electrode electrochemical corrosion cell was employed. For referencing, saturated calomel electrode was employed. For counter electrode, a platinum electrode was employed. $0.1 \mathrm{~N} \mathrm{HCl}$ solution was used as electrolytic solution. In the electrochemical cell, the selected area of about $1 \mathrm{~cm}^{2}$ of the sample is focused to the electrolytic solution. A potentiostat (IVIUM), controlled by a personal computer, and software (Ivium-soft) was used to get the Potentio-dynamic polarization curves. Prior to every experiment, the open circuit potential was noted for 60 min as per ASTM standard F212935. Polarization curves were obtained from potentio-dynamic studies. The corrosion potential $\left(\mathrm{E}_{\text {corr }}\right)$ and corrosion current $\left(\mathrm{I}_{\text {corr }}\right)$ corrosion rate were found from polarization curves by using intercept method $^{36}$. From the 1st-Stern method the corrosion rate had been found and is empirically related as described in ${ }^{37}$ :

Corrosion rate $(\mathrm{mmpy})=0.0033(e / \rho) \mathrm{I}_{\text {corr }}$

Where, $e$ is the equivalent weight $(\mathrm{g}) ; \rho$ is the density of the material $\left(\mathrm{g} / \mathrm{cm}^{3}\right)$ and $\mathrm{I}_{\text {corr }}$ is the corrosion current $\left(\mathrm{A} / \mathrm{cm}^{2}\right)$.

\section{Results and Discussion}

\subsection{Density}

Densification response of Al-Cu-Mn alloys sintered in conventional, microwave and spark plasma furnaces has been compared in Figure 1. Independent of heating mode, the compacts achieved considerable densification at higher temperature $\left(525^{\circ} \mathrm{C}\right)$. Spark plasma sintered compacts can be attributed with better sintered density ( $\sim 99 \%)$ as compared to its counterparts. This is attributed to the combination of pressure and high heating rate. Also localized plasma generation between particles, vaporization of surfaces of particles during the Spark plasma sintering process occurs; contorted shapes in the form of "necks" are developed near the contact region between particles. Development and plastic 
transformation of the necks results in sintered compacts with 99 percent density. As, exclusively temperature of surface of particles increases at an appreciable pace through selfheating, particle growth of the starting powder materials has been brought under control ${ }^{38-39}$. Whereas, in microwave sintering the enhanced densification is attributed to rapid heating rate, that limits the grain growth ${ }^{40}$. On the other hand conventional sintering involves external heating coupled with slower heating rates. Added to this there is only one driving force i.e. the thermal energy is supplied and hence least densification compared to SPS and microwave process. A similar trend is shown by the densification parameter as sintered density in both heating modes (conventional and microwave) in figure 2 . The densification parameter $(0.3)$ was achieved for compacts that underwent sintering $525^{\circ} \mathrm{C}$ in conventional furnace.

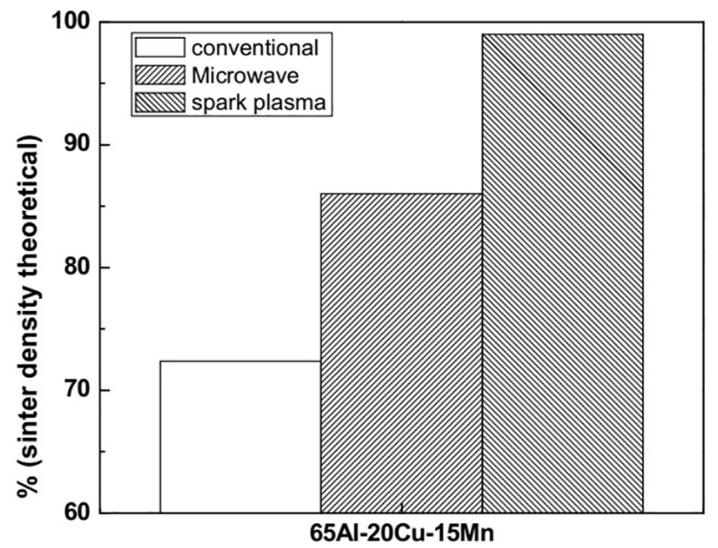

Figure 1. Sinter density with respect to heating mode and composition

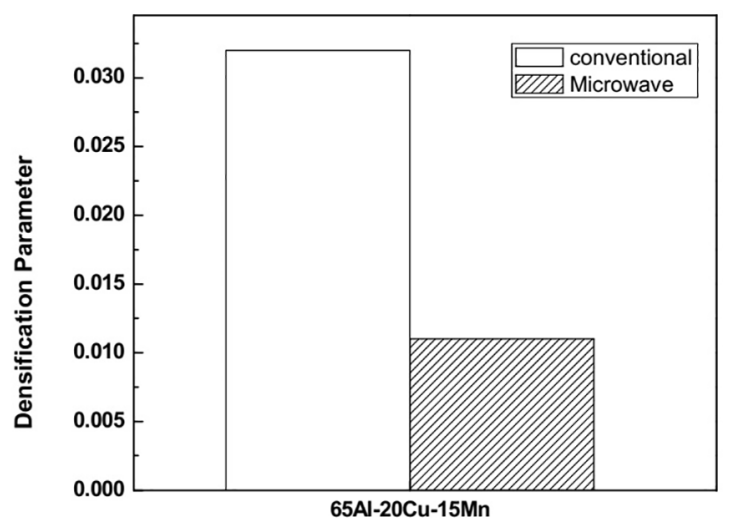

Figure 2. Densification parameter with respect to heating mode and composition

\subsection{Micro structure}

Figures 3 and 4 show optical microscope and SEM images of transverse cross section of compact at various heating modes after etching. No appreciable difference was observed. Few voids $(\sim 27 \%)$ were noticed in conventional compact \{red arrow in Fig. 3(a); but, most of these vanished as the heating rate varied. In the end, the densified Al bulk (99\%) sintered at $525^{\circ} \mathrm{C}$ for SPS was obtained. The observed black points (marked by orange arrow in Fig. 3(c)\} show the created grooves at the time of etching. The microstructures exhibit the distribution of $\mathrm{Cu}$ and $\mathrm{Mn}$ phases in Al matrix. SPS process has resulted in a much finer microstructure as compared to the conventional sintering. The grain coarsening was restricted due to higher heating rate and is obvious from Figure.4. Figure 5 displays the X-Ray diffractograms of [65Al-20Cu-15Mn] samples sintered using conventional, microwave and SPS modes. It was evident that there was no evidence of formation of intermetallic between $\mathrm{Al}$ and Mn because of the limited solid solubility at the sintering temperature. The only intermetallic that was observed are $\mathrm{Al}_{2} \mathrm{Cu}$ and $\mathrm{AlCu}$. As per Aluminium-Copper phase diagram, exclusively $\mathrm{Al}_{2} \mathrm{Cu}(\theta, 31.9$ to 33.0 at. pct $\mathrm{Cu})$ along with $\mathrm{AlCu}\left(\eta_{2}, 49.8\right.$ to 52.3 at. pct $\left.\mathrm{Cu}\right)$ phases are shown on Al-rich side of Al-Cu phase diagram, Owing to extremely higher diffusivity and less solubility limit of $\mathrm{Cu}$ in $\mathrm{Al}$, at sintering, it can be anticipated that $\mathrm{Al}(\mathrm{Cu})$ solid solution undergoes saturation in the beginning, giving rise to nucleation of $\mathrm{Al}_{2} \mathrm{Cu}$ that is the most $\mathrm{Al}$-rich intermetallic phase $^{41}$. Intermetallic phases formed in our study agree with the report by ${ }^{42}$ In Conventional and Microwave sintering processess soaking periods were higher which eventually resulted in coarse grain microstructures. No significant particle growth for the Al compacts was found ${ }^{22-23}$. It can also be seen from the Fig. 5 that the amount of intermetallic phases was much higher for conventional and microwave mode of sintering as compared to spark plasma sintered compacts. It is mainly because of very high heating rate and due to that, the diffusion time available for the formation of intermetallic is much less in case of spark plasma sintering. Added to this, the time spent by the compact during sintering in case of spark plasma sintering is much less and has resulted in much finer grain size as compared to the other two counter parts.

\subsection{Micro Hardness}

Table 1 shows the micro hardness data of sintered samples. There was not a considerable difference between hardness of conventional and microwave sintered samples. Spark plasma sintered sample showed higher hardness due to finer grain structure and high density. The considerable dip in hardness of conventional samples can be ascribed to lower final density of compacts as per Kubota et al. ${ }^{31}$. Addition of copper particulates could effectively upgrade the micro-hardness as the elemental hardness of $\mathrm{Cu}$ is higher than the other elements in the composition. Addition of $\mathrm{Cu}$ to Al will also improve the hardness through precipitation strengthening mechanism, i.e. by precipitate formation in the lattice by aging process as described by J. Sun et $\mathrm{al}^{33}$ and W.M. Rainforth et $\mathrm{al}^{43}$. 
(a)

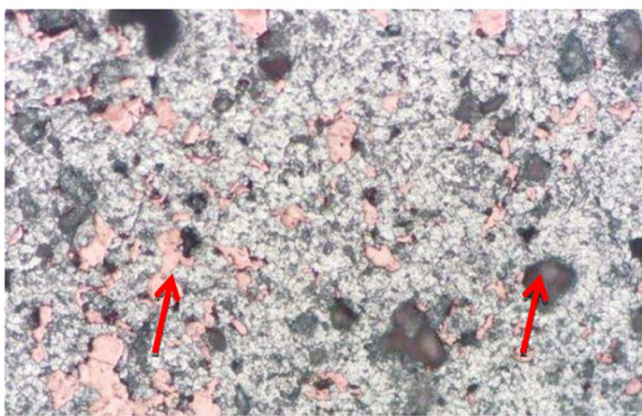

(b)

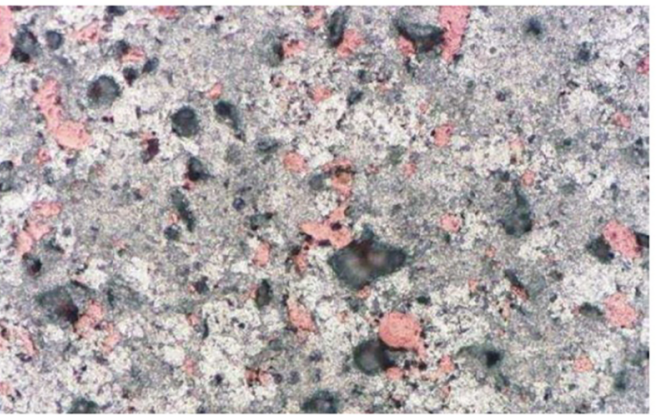

(c)

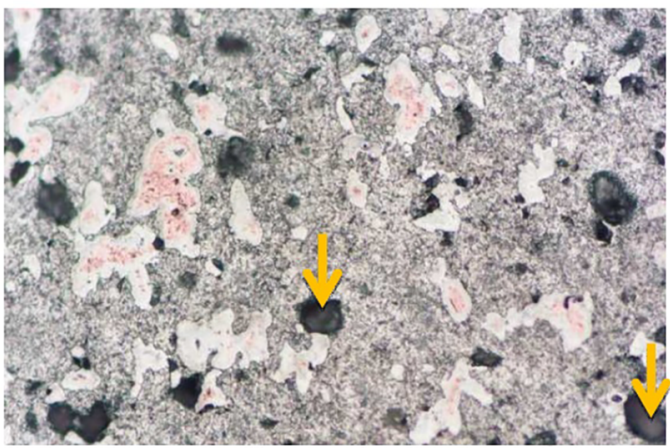

Figure 3. Optical micrographs of etched Aluminium compacts sintered in) $\mathrm{Al}-20 \% \mathrm{Cu}-15 \% \mathrm{Mn}$ (a) Conventional Sintering; (b) Microwave Sintering; (c) Spark Plasma Sintering

\subsection{Tensile test}

Table 2 provides a summary of strength and ductility data of sintered $65 \mathrm{Al}-20 \mathrm{Cu}-15 \mathrm{Mn}$ alloys. The tensile strength, yield strength and ductility follow the similar trend as micro hardness. For Al powder, Spark plasma sintering process gave a pellucid advantage over conventional powder metallurgy. As expected, conventionally sintered compacts and microwave sintered compacts showed no plastic deformation due to the presence of intermetallic compounds. In addition to this, the microstructural observations (Figure 3(a, b, and c)) revealed a dearth of microstructural development and effective absence of inter-particle bonding. Residual porosity was seen everywhere in the image along with a surfeit of prior particle boundaries. Metallurgical quality of the spark plasma sintered material

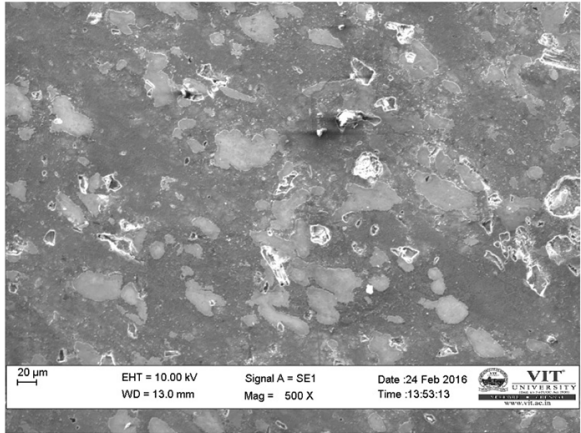

(b)

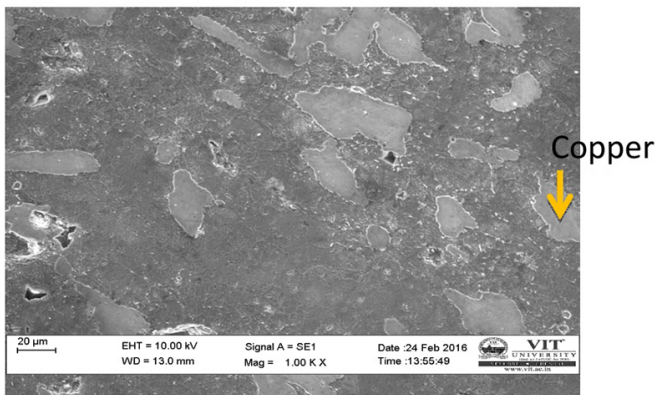

(c)

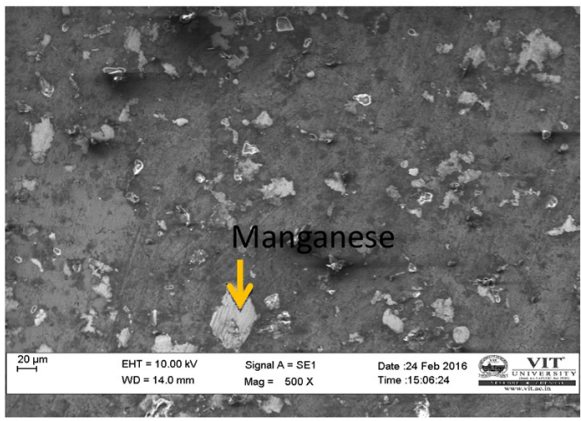

Figure 4. SEM micrographs of etched Aluminium compacts sintered in) Al-20\% Cu-15\%Mn (a) Conventional Sintering; (b) Microwave Sintering; (c) Spark Plasma Sintering

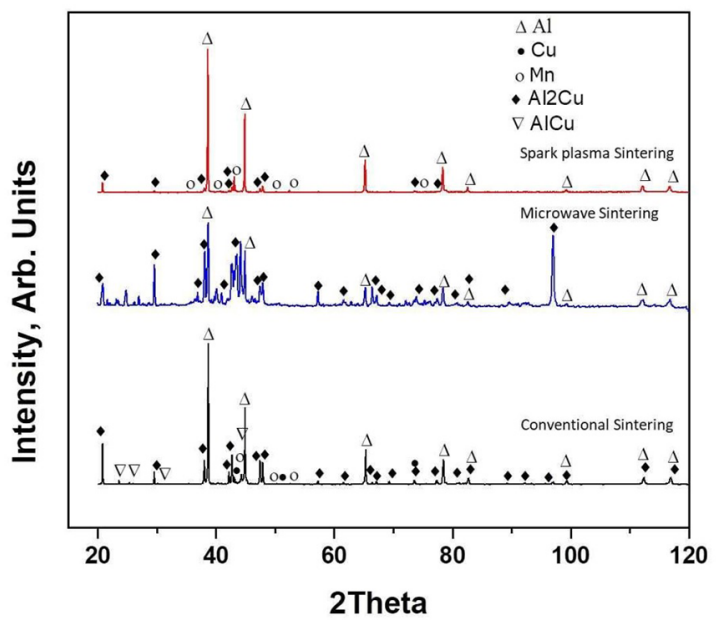

Figure 5. XRD curves of Al -20Cu-15Mn compact (a) Conventional; (b) Microwave; (c) Spark Plasma 
Table 1. Micro-Hardness and Grain sizevalues of sintered samples

\begin{tabular}{|c|c|c|c|}
\hline Composition & Conventional, $\mathrm{HV}_{0.02}$ & Microwave, $\mathrm{HV}_{0.02}$ & Spark plasma, $\mathrm{HV}_{0.02}$ \\
\hline \multirow{2}{*}{$65 \mathrm{Al}-20 \mathrm{Cu}-15 \mathrm{Mn}$} & $57.3 \pm 1.2$ & $63.06 \pm 0.8$ & $116.04 \pm 0.45$ \\
\hline & Grain Size $36 \mu \mathrm{m}$ & Grain Size $24 \mu \mathrm{m}$ & Grain Size $15 \mu \mathrm{m}$ \\
\hline
\end{tabular}

Table 2. Ultimate Tensile Strength, Yield Strength and percentage elongation for $65 \mathrm{Al} 20 \mathrm{Cu}-15 \mathrm{Mn}$ compositions

\begin{tabular}{lccccccccc}
\hline \multirow{2}{*}{ Material } & \multicolumn{3}{c}{ Ultimate Tensile Strength } & \multicolumn{3}{c}{$\begin{array}{c}\text { Yield Strength } \\
{[\mathrm{MPa}]}\end{array}$} \\
\cline { 2 - 26 } & CS & MWS & SPS & CS & MWS & SPS & CS & MWS & SPS \\
\hline $65 \mathrm{Al}-20 \mathrm{Cu}-15 \mathrm{Mn}$ & $45 \pm 3.5$ & $63 \pm 2.1$ & $89 \pm 1$ & $32 \pm 1.2$ & $51 \pm 1.7$ & $67 \pm 0.2$ & $5 \pm .5$ & $12 \pm .3$ & $23 \pm .1$ \\
\hline
\end{tabular}

Table 3. Potentio-dynamic polarization values for the conventional, Microwave and Spark plasma Sintered samples.

\begin{tabular}{lcccc}
\hline Composition & Mode of Sintering & $\mathrm{I}_{\text {corr. }}\left(\mathrm{Amp} . / \mathrm{mm}^{2}\right)$ & $\mathrm{E}_{\text {corr. }}($ Volt $)$ & Corr. Rate $(\mathrm{mm} /$ year) \\
\hline \multirow{3}{*}{ 65Al- 20Cu- 15Mn } & Conventional & 1.7918 & -0.002 & 2.003 \\
& Microwave & 1.6466 & 0.007 & 1.826 \\
& Spark pasma & 0.7752 & 0.001 & 0.903 \\
\hline
\end{tabular}

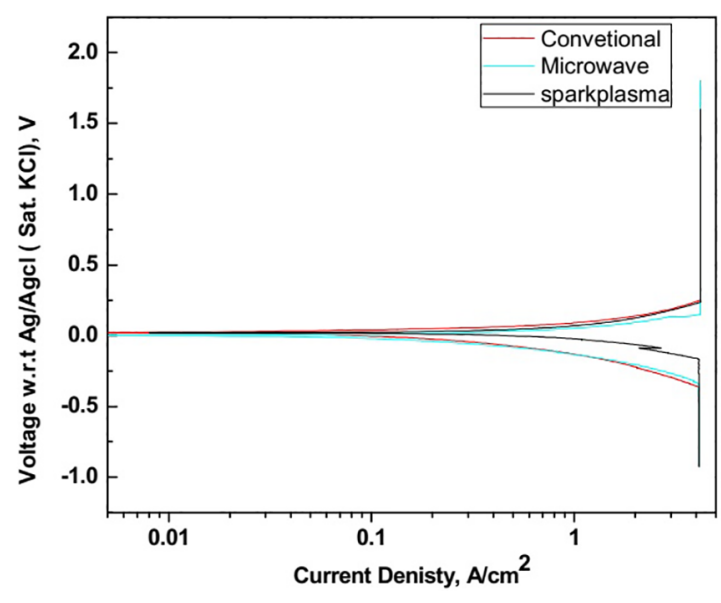

Figure 6. The potentio-dynamic polarization curves of $\mathrm{Al}-20 \mathrm{Cu}-$ $15 \mathrm{Mn}$ compact sintered at $525^{\circ}$

was homogeneous in the microstructure (Figure $3(\mathrm{c}))^{33}$. Due to the presence of a fine grained microstructure, spar plasma sintered sample exhibited very high strength without causing much damage to its ductility. Potentio-dynamic polarization curves of samples sintered at $525^{\circ} \mathrm{C}$ are shown as in Figure 6. It was obvious that all spark plasma sintered samples had higher corrosion current densities as compared to the microwave and conventional samples. Table 3 shows that potendio-dynamic curve values for the sintered samples. The Spark plasma sintered alloy depicts a decrease in current density in comparison with counter parts. Lower corrosion resistance was noted for finer grain structures of the $\mathrm{Al}-\mathrm{Cu}-\mathrm{Mn}$ alloy (bigger areas of $\mathrm{Al}_{2} \mathrm{Cu}$ that are more prone to corrosive action). As heating rate is increased, the corrosion current density of the material decreased by $50 \%$ for SPS. The percentage of porosity reduced the chance of corrosion attack due to the reduction in anodic region on the surface layers of the sintered compact in spark plasma sintering as compared with the other two sintering methods. Higher corrosion potential $\left(\mathrm{E}_{\text {corr }}\right)$, lower corrosion current density $\left(\mathrm{I}_{\text {corr }}\right)$ and corrosion rate for compacts sintered in conventional were observed. This is consistent with the results reported by Padmavathi et $\mathrm{al}^{16}$.

\section{Conclusion}

The selected alloy composition Al-20Cu-15Mn was successfully prepared using powder metallurgy route and various sintering processes. The sintered density was highest by spark plasma sintering followed by microwave and conventional, respectively. Mechanical properties were also found to be highest in spark plasma sintered samples followed by microwave and conventional sintering. Microwave and spark plasma sintering produce finer microstructure and smaller pore size than conventionally sintered sample. Corrosion resistance is highest for spark plasma sintered compact followed by conventional and microwave sintering.

\section{Acknowledgements}

The authors gratefully acknowledge VIT University, Vellore for the support through Seed Grant for Research.

\section{References}

1. AMS International. Powder Metal Technologies and Applications. Volume 7. Materials Park: ASM International; 1998.

2. Beaumont FV. Aluminium P/M: Past, Present and Future. International Journal of Powder Metallurgy. 2000;36(6):41-43.

3. Lall C, Heath W. P/M Aluminium Structural Parts - Manufacturing and Metallurgical Fundamental. International Journal of Powder Metallurgy. 2000;36(6):45-50. 
4. Hunt WH Jr. New Directions in Aluminium-Based P/M Materials for Automotive Applications. International Journal of Powder Metallurgy. 2000;36(6):51-60.

5. Schaffer GB, Sercombe TB, Lumley RN. Liquid phase sintering of aluminium alloys. Materials Chemistry and Physics. 2001;67(1-3):85-91.

6. Udomphol A. Aluminium and its alloys. Nakhon Ratchasima: Suranaree University of Technology; 2007. Available from: $<$ http://eng.sut.ac.th/metal/images/stories/pdf/05_Titanium $\% 20$ and $\% 20$ titanium $\% 20$ alloys.pdf $>$. Access in: 17/02/2018.

7. Whittaker AG, Mingos DM. Microwave-assisted solid-state reactions involving metal powders. Journal of the Chemical Society, Dalton Transactions. 1995;(12):2073-2079.

8. Roy R, Agrawal D, Cheng J. Gedevanishvili S. Full sintering of powdered-metal bodies in a microwave field. Nature. 1999;399:668-670.

9. Rödiger K, Dreyer K, Gerdes T, Willert-Porada M. Microwave sintering of hardmetals. International Journal of Refractory Metals and Hard Materials. 1998;16(4-6):409-416.

10. Takayama S, Saiton Y, Sato M, Nagasaka T, Muroga T, Ninomiya Y. Microwave sintering for metal powders in the air by nonthermal effect. In: Proceedings of $9^{\text {th }}$ International Conference on Microwave and High Frequency Heating; 2003 Sep 1-5; Loughborough, UK. p. 369-372.

11. Sethi G, Upadhyaya A, Agrawal D. Microwave and Conventional Sintering of Premixed and Prealloyed Cu-12Sn Bronze. Science of Sintering. 2003;35(2):49-65.

12. Anklekar RM, Agrawal DK, Roy R. Microwave sintering and mechanical properties of PM copper steel. Powder Metallurgy. 2001;44(4):355-362.

13. Anklekar RM, Bauer K, Agrawal DK, Roy R. Improved mechanical properties and microstructural development of microwave sintered copper and nickel steel PM parts. Powder Metallurgy. 2005;48(1):39-46.

14. Panda SS, Upadhyaya A, Agrawal D. Effect of conventional and microwave sintering on the properties of yttria alumina garnet-dispersed austenitic stainless steel. Metallurgical and Materials Transactions A. 2006;37(7):2253-2264.

15. Panda SS, Singh V, Upadhyaya A, Agrawal D. Sintering response of austenitic (316L) and ferritic (434L) stainless steel consolidated in conventional and microwave furnaces. Scripta Materialia. 2006;54(12):2179-2183.

16. Padmavathi C, Panda SS, Agarwal D, Upadhyaya A. Effect of Microstructural Characteristics on Corrosion Behaviour of Microwave Sintered Stainless Steel Composites. In: Proceedings of Materials Science \& Technology Conference and Exhibition (MS\& $\left.T^{\prime} 06\right)$; 2006 Oct 15-19; Cincinnati, OH, USA.

17. Padmavathi C, Upadhyaya A, Agrawal D. Corrosion behavior of microwave-sintered austenitic stainless steel composites. Scripta Materialia. 2007;57(7):651-654.

18. Gupta M, Wong WLE. Enhancing overall mechanical performance of metallic materials using two-directional microwave assisted rapid sintering. Scripta Materialia. 2005;52(6):479-483.
19. Annamalai R, Upadhyaya A, Agrawal D. An investigation on microwave sintering of $\mathrm{Fe}, \mathrm{Fe}-\mathrm{Cu}$ and $\mathrm{Fe}-\mathrm{Cu}-\mathrm{C}$ alloys. Bulletin of Material Science. 2013;36(3):447-456.

20. Raja Annamalai A, Nekatibeb F, Upadhyaya A, Agrawal DK. Effect of heating mode on sinterability of carbonyl iron compacts. Materials Research Innovations. 2013;17(1):10-16.

21. Garay JE. Current-Activated, Pressure-Assisted Densification of Materials. Annual Review of Materials Research. 2010;40;445-468.

22. Munir Z, Anselmi-Tamburini U, Ohyanagi M. The effect of electric field and pressure on the synthesis and consolidation of materials: A review of the spark plasma sintering method. Journal of Materials Science. 2006;41(3):763-777.

23. Xie G, Ohashi O, Yamaguchi N, Song M, Mitsuishi K, Furuya $\mathrm{K}$, et al. Reduction of Surface Oxide Films in Al-Mg Alloy Powders by Pulse Electric Current Sintering. Journal of Materials Research. 2004;19(3):815-819.

24. Xie G, Ohashi O, Sato T, Yamaguchi N, Song M, Mitsuishi K, et al. Effect of $\mathrm{Mg}$ on the Sintering of Al-Mg Alloy Powders by Pulse Electric-Current Sintering Process. Materials Transactions. 2004;45(3):904-909.

25. Xie G, Ohashi O, Yoshioka T, Song M, Mitsuishi K, Yasuda $\mathrm{H}$, et al. Effect of Interface Behavior between Particles on Properties of Pure Al Powder Compacts by Spark Plasma Sintering. Materials Transactions. 2001;42(9):1846-1850.

26. Xie G, Ohashi O, Chiba K, Yamaguchi N, Song M, Furuya K, et al. Frequency effect on pulse electric current sintering process of pure aluminum powder. Materials Science and Engineering: A. 2003;359(1-2): 384-390.

27. Xie G, Ohashi O, Song M, Furuya K, Noda T. Behavior of oxide film at the interface between particles in sintered Al powders by pulse electric-current sintering. Metallurgical and Materials Transactions A. 2003;34(3):699-703.

28. Xie G, Ohashi O, Song M, Mitsuishi K, Yasuda H, Furuya K, et al. Electron microscopic observation of interfaces of aluminium powder compacts prepared by spark plasma sintering. Journal of Electron Microscopy. 2002;51(Suppl 1):149-153.

29. Xie G, Ohashi O, Song M, Mitsuishi K, Yasuda H, Furuya K. Reduction mechanism of surface oxide films and characterization of formations on pulse electric-current sintered Al-Mg alloy powders. Applied Surface Science. 2005;241(1-2):102-106.

30. Xie G, Ohashi O, Chiba K, Yamaguchi N, Song M, K. Furuya $\mathrm{K}$, et al. Frequency effect on pulse electric current sintering process of pure aluminum powder. Materials Science and Engineering: A. 2003;359(1-2):384-390.

31. Kubota M. Properties of nano-structured pure Al produced by mechanical grinding and spark plasma sintering. Journal of Alloys and Compounds. 2007;434-435:294-297.

32. Nayer A. The Metal Databook. New York: McGraw-Hill; 1997.

33. Sun Y, Kulkarni K, Sachdev AK, Lavernia EJ. Synthesis of $\gamma$-TiAl by Reactive Spark Plasma Sintering of Cryomilled Ti and Al Powder Blend, Part I: Influence of Processing and Microstructural Evolution. Metallurgical and Materials Transactions A. 2014;45(6):2750-2758. 
34. Kang SJ. Sintering: Densification, Grain Growth \& Microstructure. London: Elsevier Butterworth-Heinemann; 2005.

35. ASTM International. ASTM F2129-17b - Standard Test Method for Conducting Cyclic Potentiodynamic Polarization Measurements to Determine the Corrosion Susceptibility of Small Implant Devices. West Conshohocken: ASTM International; 2017.

36. Fontana MG. Corrosion Engineering. New York: McGraw-Hill; 1986.

37. Bardal E. Corrosion and Protection. London: Springer Science; 2004.

38. Pert E, Carmel Y, Birnboim A, Olorunyolemi T, Gershon $\mathrm{D}$, Calame J, et al. Temperature Measurements during Microwave Processing: The Significance of Thermocouple Effects. Journal of the American Ceramic Society. 2001;84(9):1981-1986.
39. Lide DR, ed. RC Handbook of Chemistry and Physics 79th Edition: A Ready-Reference Book of Chemical. Boca Raton: CRC Press, Boca Raton; 1998.

40. Sweet GA, Brochu M, Hexemer RL Jr., Donaldson IW, Bishop DP. Microstructure and mechanical properties of air atomized aluminum powder consolidated via spark plasma sintering. Materials Science and Engineering: A. 2014;608:273-282.

41. Hug E, Bellido N. Brittleness study of intermetallic $(\mathrm{Cu}, \mathrm{Al})$ layers in copper-clad aluminium thin wires. Materials Science and Engineering: A. 2011;528(22-23):7103-7106.

42. Chen CY, Hwang WS. Effect of Annealing on the Interfacial Structure of Aluminum-Copper Joints. Materials Transactions. 2007;48(7):1938-1947.

43. Ghazali MJ, Rainforth WM, Jones H. Dry sliding wear behaviour of some wrought, rapidly solidified powder metallurgy aluminium alloys. Wear. 2005;259(1-6):490-500. 